\title{
THE VEGETATION AND FLORA OF DEAL ISLAND, KENT GROUP
}

\author{
by Stephen Harris and Georgina Davis
}

(with two text-figures and an appendix)

Harris, S. \& avis, G., 1995 (30:vi): The vegetation and flora of eal Island, Kent Group. Pap. Proc. R. Soc. Tasm. 129:43-51.

https://doi.org/10.26749/rstpp.129.43 ISSN 0800-4 703. Parks and Wildlife Service, Department of Environment and Land

Management, GPO Box 44A, Hobart, Tasmania, Australia 7001.

There are eight formations mapped for eal Island comprising forests and woodlands, scrub, sedgeland, grassland and a coastal complex. Tussock grassland, which results from burning and clearing of Allocasuarina forest, occurs on the limestone soils, while the soils formed directly over granite are clothed with Eucalypt-dominated scrub and wondland with a heathy or shrubby understorey. A total of 176 plant taxa are recorded, of which only two are Tasmanian endemics. About one-quarter of the flora comprise exotic species. A distinct Bassian floristic element is present, which includes some Eremean flora.

Key Words: Bass Strait, vegetation, Tasmania, island biogeography, Deal, Kent

\section{INTRODUCTION}

Deal Island is the largest (1575 ha) of the Kent Group of islands situated in Eastern Bass Strait, midway between Flinders Island and Wilsons Promontory. It is a rugged granite island, with lenses of Tertiary limestone mantling the topographically more subdued areas on the northern and western parts. The highest point is about $395 \mathrm{~m}$ above sea level. The other islands comprising the group are Dover and Erith, which are joined to each other at low tide by a narrow isthmus, and the more outlying smaller islands of the group, North East and South West Islands.

Deal Island has been the site of a lightstation since 1843 . North East and South West Islands are the sites of recently erected automatic lighthouses. Erith Island has been used for grazing for many years. The only permanent human habitation in the islands has been the continuous occupation of Deal Island by lightkeepers and their families.

Deal Island was formally transferred to the Commonwealth on 1 July 1915 and was gazetted a Wildlife Sanctuary on 28 July 1941, effective under the Tasmanian National Parks and Wildlife Act 1970. The island was nominated for the Register of the National Estate on 23 December 1976, and registered on 21 March 1978.

Botanical exploration of Deal Island has been sporadic and opportunistic, resulting in the publication of incomplete species lists and fragmentary accounts of the vegetation. Robert Brown made extensive botanical collections in 1803 , especially of marine algae. Visits by parties from the Victorian Field Naturalists Club have made important contributions, but the first published list of Deal Island flora is that of Baron von Mueller (1885). The historical background to this collection has been discussed by Whinray (1993), who is known to have visited the island many times and published the results of his work (1971a, b). Hope \& Hope (1968) attempted a synthesis of information about the island and made a preliminary description of the island's vegetation.

In contrast to the lack of any systematic account of the terrestrial flora, the marine flora and fauna around Deal Island have been systematically explored and more recently documented.

Baseline information on the composition and distribution of Tasmanian marine communities is meagre (Edgar 1984) but waters around the Kent Group have received some attention since the 1803 visit of Robert Brown (Le Souef 1891, Bennett \& Pope 1960, King 1973, Last 1979, Kuiter 1981, Edgar 1984). Edgar recommended a marine reserve around the Kent Group on the basis of a very diverse marine fauna. He also noted the exceptional water clarity due to remoteness from any major source of runoff or pollution (Edgar 1984).

The Kent Group is located at the convergence of the three Southern Australian marine biogeographic provinces (Peronian, Maugean and Flindersian), resulting in a high faunal diversity. The number of seaweed species is not notably greater than elsewhere in the rich Bass Strait area. Edgar (1984) discussed the possibility of similar marine ecosystems occurring at Wilsons Promontory and around other islands, and concluded that the Kent Group was probably unique because of the diversity of habitats, different degrees of exposure, situation with respect to water currents, and absence of the influence of large estuaries.

Throughout the Quaternary, Bass Strait islands have, of course, alternated as islands and as high points on a broad Bassian plain. The peopling of the southeastern extremity of the continent, the patterns of movement of people across the landscape and the nature of vegetation changes and environmental fluctuations during the Quaternary and Holocene periods are issues of great interest to archaeologists and biogeographers (e.g. Bowdler 1984, Orchiston 1984, Jones 1969).

Accounts of the vegetation and flora of Bass Strait islands are few, especially given that there are just over 100 vegetated islands in eastern Bass Strait alone. Contributions to the biogeography of these islands are, therefore, a source of interest to a wide range of workers.

This paper is based on an unpublished report (Harris \& Davis 1990) prepared for the Australian Heritage Commission by the present authors.

\section{METHODS}

Two weeks were spent on the island in May 1990. During this time the island was traversed, in order to sample the full range of vegetation types likely to be found on the island. Apparent vegetation boundaries were marked on a black and 
white 1:40 000 aerial photograph dated 6 February 1982. As thephotograph pre-dated the last fire, some modifications to the vegetation map were required. The $\mathrm{pH}$ of some soils was measured in the field by a CSIRO field $\mathrm{pH}$ test kit (Inoculo laboratories).

Th ree transect sketches were made with a tape, compass and clinometer on areas of sandy coast.

Human effects on islands can have a huge impact, so any study of island vegecation should examine the history of huma in contact. An examination of relevant historica! sources was made to identify past impressions of Deal Island.

The visit was untimely for flowering, but specimens were collected of all species observed. Suitable specimens were lodged in the Tasmanian Herbarium.

\section{A BRIEF HISTORY OF THE ISLAND}

The Kent Group was discovered by Matthew Flinders in 1798 , during a voyage to Preservation Island to rescue survivors of the Sydney Cove wreck. It was the investigations of Flinders, following the Sydney Cove episode, which led to the discovery of the numerous colonies of Australian Fur Seal. The exploitation of the seal populations in Bass Strait quickly followed.

In 1803, seven years before publication of his monumental Prodromus Florae Novae Hollandiae ..., the great British botanist Robert Brown landed on Deal Island and made extensive collections. As a result, the island is the type locality for many species of marine algae as well as terrestrial species such as Myoporum insulare.

Only four years before Robert Brown's landing, Lieutenant Flinders and Dr George Bass sailed past the Kent Group on their circumnavigation of Van Diemen's Land. In a contemporary account, Collins (1802) reports Bass' journal description:

"This small group [of islands] appears to be formed of granite, which is imperfectly concealed by long straggling dwarfish brush, and some few still more diminutive trees, and seems cursed with a sterility that might safely bid defiance to Chinese industry itself. Nature is either working very slowly with those islands, or has altogether ceased work upon them, since a more wild deserted place is not easily to be met with. Even the birds seemed not to frequent them in their usual numbers."

Only a year before Robert Brown's landing, Captain Nicolas Baudin sailed past the Kent Islands, dismissing them with the comment, "None of the islands appeared to me to offer much in the way of resources for navigators" (Cornell 1974).

Some of the sealers settlements in Eastern Bass Strait were amongst the earliest European settlements outside Sydney Cove. For example, Kent Bay on Cape Barren Island was the site of a permanent sealers camp in 1798 . When sealing commenced on Deal Island is uncertain but, since this island is more rugged and remote, it probably postdated the beginning of the slaughter in the Furneaux Group. It is not known how permanent the sealers camp at Garden Cove was. There is no apparent trace of it today. In 1831, George Augustus Robinson visited the camp and wrote in his journal (Plomley 1966):
"Proceeded across the island for about two miles and came to the opposite coast where is a sandy beach and where the sealers have fixed their abode. The parh across the hill is romantic, winding through some tea tree scrub. On reaching the huts we found the sealers had been gone for some time by the appearance of the hurs. The sealers have several rude huts or hovels, which are built of bags tied with hay bands, and thatched with grass. The situation is in a valley and a stream of water runs through the settlement, but is very indifferent and of a sweet or aluminous taste. They have several gardens. Found some poultry; also some flour, potatoes and a musket in a hut. Found one whaleboat and two dinghies."

When Bass and Flinders proved the separation by sea of Van Diemen's Land from the New Holland main in 1798, they opened up the Strait as part of a major shipping roure for sailing vessels from Europe travelling across the Indian Ocean, bound for Sydney Cove. Murray Pass and some of the Coves around Deal Island became important as anchorages during storms. The numerous rocks and islands, particularly in eastern Bass Strait, quickly began taking their toll of shipping, and the erection of lighthouses became an urgent need.

Murray-Smith (1980) noted that

"the leading authority on Australian constitutional history of the period, Professor J. M. Ward, has pointed out in his work 'Earl Grey and the Australian Colonies' that the building of the Deal Island lighthouse was the first example of inter-colonial responsibility in the history of the movement towards the federation of those colonies and the evolution of the Australian Government today."

\section{VEGETATION COMMUNITIES}

\section{Poa poiformis Tussock Grassland}

This formation occupies about 305 ha, or $19.4 \%$ of the island and is generally confined to the areas of relatively more fertile and uniform soil cover. Such soils are more or less coincidental with the extent of limestone on flat to gently sloping areas.

The projective foliage cover of the dominant Poa poiformis varies but is commonly $100 \%$ on the areas more distant from the lightstation, out of range of domestic animal grazing.

Species occasionally emergent above, or codominant with Poa poiformis are bracken (Pteridium esculentum) and coastal sword sedge (Lepidosperma gladiatum). The intertussock flora most commonly comprises Cirsium vulgare seedlings, Fumaria muralis, Hydrocotyle muscosa, Gnaphalium collinum, Oxalis perennans, Isolepis nodosus, Geranium sp., Senecio quadridentatus, Centaurium erythraea, Trifolium sp., Gonocarpus sp., Anagallis arvensis, Aira caryophyllea and Hypericum gramineum. Following a time in 1987, thistles were very abundant (Max Lucas, Assistant Lightkeeper, pers. comm.), but the dense growth of the tussocks has effectively suppressed thistles in many areas.

The boundaries of the community are fairly sharp and coincide with higher soil fertility and fire boundaries, for example the boundary above Wintry Creek, near Winter Cove. The community mostly adjoins Allocasuarina 
verticillata dominated formations and there appears to be active invasion of the grassland by $A$. verticillata in some places.

\section{Stipa stipoides Tussock Grassland}

This formation occupies about $0.6 \%$ of the island and is confined to a narrow strip around the more exposed areas of the coast, forming a zone exposed to salt spray. Soil type or fire frequency do not appear to be controlling factors in the distribution of this grass except in an indirect way. The most extensive area of Stipa stipoides tussock grassland is on the slopes above Little Squally Bay due south of the lightstation, where there is high exposure to the predominant storm weather direction and where protective tree and shrub cover has been eliminated.

The community is of open structure, with Stipa rarely exceeding 30\% ground cover. Bare ground and rock are common. Associated plants are typical of rocky shore vegetation and include Apium prostratum, Disphyma crassifolium, Calocaphalus brownii (on unstable slopes) and Cyathodes juniperina.

\section{Beach Dune Complex}

Beaches are a minor mapping unit, comprising less than 1\% of the coast, but they have distinct plant assemblages. The sand dunes occur at East Cove, Garden Cove and Winter Cove. All differ in degree of exposure, landform profile and plant species composition.

At Garden Cove the dunes are occupied by Spinifex sericeus, Lepidosperma gladiatum, Isolepsis nodosus, Senecio lautus and Pteridium esculentum. Euphorbia paralius and Cakile maritima occur on the shoreward of the dune (fig. 1A).

At Winter Cove, the beach is exposed to direct easterlies but is otherwise fairly protected. The beach system here comprises a wide berm occupied by Spinifex sericeus and Isolepis nodosus. At the southern extremity of the beach, the berm is colonised by a patch of Ammophila arenaria. A foredune and swale occur to the rear of the berm. The foredune is vegetated by Lepidosperma gladiatum and Pteridium esculentum, with occasional fire-killed shrubs of Allocasuarina verticillata. The swale is vegetated by Dichondra repens, Parietaria debilis, Lepidosperma gladiatum, Pteridium esculentum and Poa poiformis (fig. 1B).

At East Cove, the native vegetation is depleted because it has been displaced by exotics such as Euphorbia paralius, which forms a dense ground cover, and Diplotaxis muralis further up the slopes. Atriplex prostata, Bromus diandrus and Zygophyllum billardieri occur in the dune. On the weathered limestone, and even the limestone itself, behind the beach (above and below the track), Threlkeldia diffusa occurs as sometimes thick mats. Allocasuarina verticillata dominates the slopes immediately behind the beach (fig. 1C).

\section{Cliff Complex and Steep Granite Slopes near the Coast}

A high proportion of the coast is cliffed or at least comprises very steep granite slopes. The species occurring on the cliffs and slopes are often very similar to those on granite areas with skeletal soils, further inland, except in the more exposed sites where a typically coastal flora becomes dominant. The microtopographic variation gives rise to variable soil and moisture conditions which provide numerous different niches for plant species. There are rarely sections where an ordered zonation can be seen, but broadly there are three zones on exposed granite coasts in Bass Strait. The sequence is illustrated below:

sea — Sarcocornia quinqueflora zone - Stipa stipoides zone - Poa poiformis zone

Sarcocornia is occasional on lower parts of the shore, especially on gravel accumulations in sites subject to tidal influence. Asplenium obtusatum occurs in shaded places amidst large boulders in crevices. Lobelia alata is common in similar sites.

N

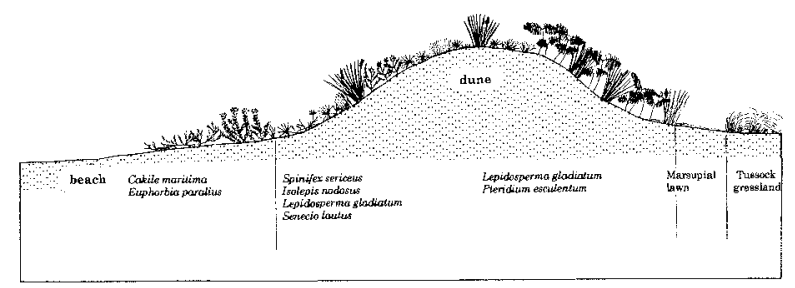

A

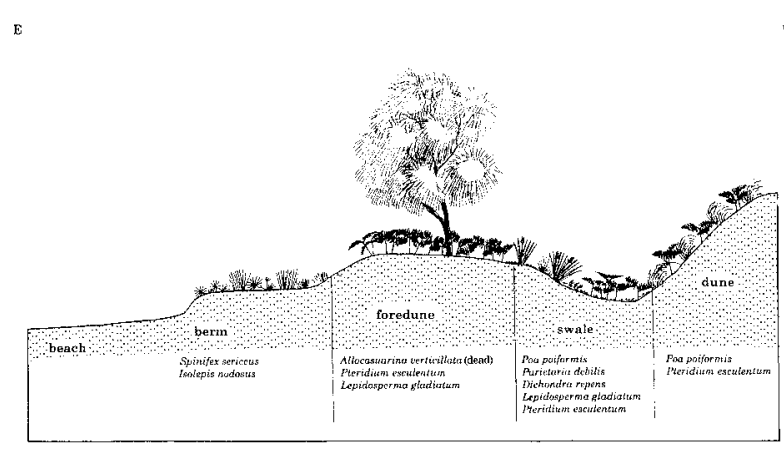

B

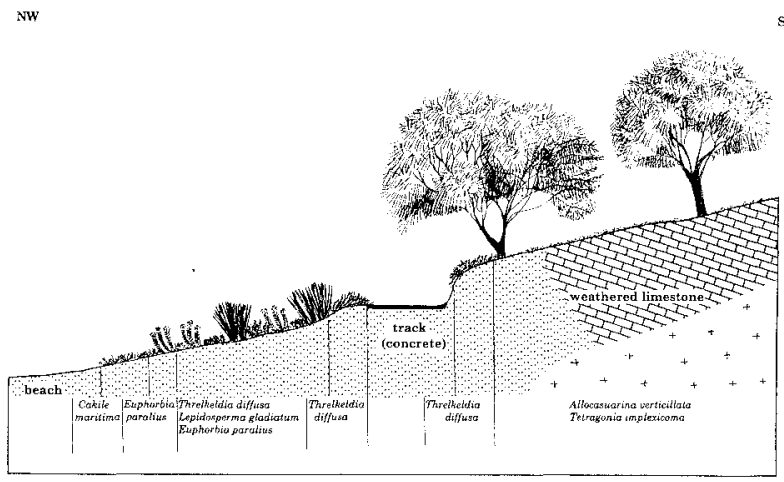

C

FIG. 1 - Vegetation profiles along three sandy coastal transects at (A) Garden Cove, (B) Winter Cove and (C) East Cove. 
Stipa stipoides and Isolepis nodosus also grow in narrow crevices along with species such as Crassula sieberana, Gnaphalium collinum, Plantago coronopus, Apium insulare and A. prostratum, Calandrinia calyptrata and Fumaria muralis. Stipa stipoides commonly occurs with these species as well as with Vellereophyton dealbatum and Carpobrotus rossiz. Alyxia buxifolia, Olearia argophylla and dwarf shrubs of Leucopogon parviflorus and Leptospermum laevigatum commonly occur in very exposed situations high on cliffs, in deep, wide fissures high on cliffs and on large boulder summits near the shore. Other species on the cliff summit berween the Lighthouse and Little Squally Cove include Stylidium graminifolium, Senecio lautus, Helichrysum paralium and Ixiolaena supina.

The Poa poiformis zone contains fewer typically coastal species.

The rare Ixiolaena supina occurs typically in pendant mats on granite or arkose cliffs around the coast. At Little Squally Cove, the species occurs with Crassula sieberana, Apium prostratum, Lobelia alata, Disphyma crassifolium and Stipa stipoides.

In some areas on the most exposed sections of coast, where the granite is deeply weathered and breakdown products have formed steep unstable colluvial slopes, Calocephalus brownii is especially abundant.

\section{Eucalyptus nitida Forests, Woodlands and Shrublands}

Eucalyptus nitida formations occupy $47.5 \%$ (747 ha) of the island, mainly on the more rugged southern and eastern hills. Communities dominated by E. nitida are most common on the granite substrate, whereas Allocasuarina verticillata displaces Eucalyptus on limestone.

Eucalyptus nitida dominated communities are mapped as either forests or shrublands, but there is a complete gradation in height classes. Pockets of woodland were omitted for the sake of clarity in the map.

The E. nitida on Deal Island is commonly of malleeform with pronounced coppicing. Based on the size of some mallee clumps, some lignotubers are up to $5-6 \mathrm{~m}$ in diameter. On deeper soils, particularly in areas that have escaped a high fire frequency, there are eucalypts with single main stems.

On flatter areas, where some soil or colluvium has been able to accumulate, there is usually a dense, shrubby understorey comprising species such as Pultenaea daphnoides, Leptospermum laevigatum, L. scoparium, Acacia mucronata, Epacris impressa and Monotoca elliptica. On the steeper granite slopes, ridges and hill tops, where there is only intermittent skeletal soil, the eucalypts are shorter and heavily coppiced. There is much more exposed bedrock, and the understorey is, therefore, more sparse. Common species include Kunzea ambigua, Leptospermum laevigatum, Allocasuarina monilifera, L. scoparium, Pultenaea daphnoides and Goodenia ovata. Species in this formation which are rare to the island include Dodonaea viscosa and Schizea bifida. Crassula sieberana is fairly common in narrow crevices in the granite.

\section{Allocasuarina verticillata Forests and Woodlands}

Allocasuarina verticillata low open woodland, low open forest and low closed forest together comprise $24.6 \%$ or 387 ha of the island, with low open woodland being the most common formation. Communities dominated by $A$. verticillata occupy limestone substrates on the northern part of the island. Allocasuarina formations occupy slopes around the granite coastline.

The Allocasuarina usually forms pure stands but occasionally shares the canopy with Leptospermum laevigatum and Melaleuca ericifolia. Associated species composition depends on proximity to onshore, salt-laden winds, geology, soil depth and moisture availability. On the limestone slopes at East Cove (fig. 2) where soils are shallow, alkalinity is high, and there is influence from the sea, Leucopogon parviflorus, Leptospermum laevigatum and Helichrysum paralium occur as a very sporadic shrub "layer". Although there is a great deal of bare ground, there are a number of low shrubs and herbs which include Threlkeldia diffusa, Diplotaxis muralis, Tetragonia implexicoma, Dichondra repens, Lepidosperma gladiatum and Rhagodia candolleana.

Above the head of the valley leading down to Garden Cove, a patch of $A$. verticillata woodland was burnt in the 1987 fire, leaving only a small unburnt patch. In the burnt area, apart from prolific regeneration of $A$. verticillata, the species recorded included Pomaderris paniculosa ssp. paralia, Clematis microphylla, Gyrostemon thesioides, Swainsonia lessertifolia, Dampiera stricta, Gnaphalium collinum, Pseudognaphalium luteo-album and Danthonia racemosa. In this area, the friable loamy soil had a measured $\mathrm{pH}$ of 8 .

A. verticillata occurs as low closed forest in some areas, especially on the steep slopes below the cliffs, west of the lighthouse. Callitris rhomboidea is an occasional component of this formation.

\section{Lepidosperma gladiatum Sedgeland}

This formation occupies only about 5 ha, which is about $0.3 \%$ of the island. The species occurs on the beach systems described above and sometimes forms locally dense patches on some of the dune systems.

At the eastern end of Squally Bay, there is a slope of limestone, which is dominated by Lepidosperma gladiatum in association with Poa poiformis, Pteridium esculentum and Carex apressa. Callitris rhomboidea, less than $1 \mathrm{~m}$ in height and severely wind pruned, occurs patchily, especially on the slope immediately west of Ferny Spring Gully at the eastern head of Squally Cove.

\section{Myoporum insulare Scrub Open and Closed}

This formation is the smallest mappable vegetation type, occupying no more than 1.5 ha south of East Cove. It is described here because it is so distinctive, and also because both the species and the vegetation type may have been more widespread on the island in the past.

The stand occurs on a moderate slope with north to northwest aspect, close to the shore. The substrate is calcareous sand with limestone cobbles occupying $95 \%$ of the 


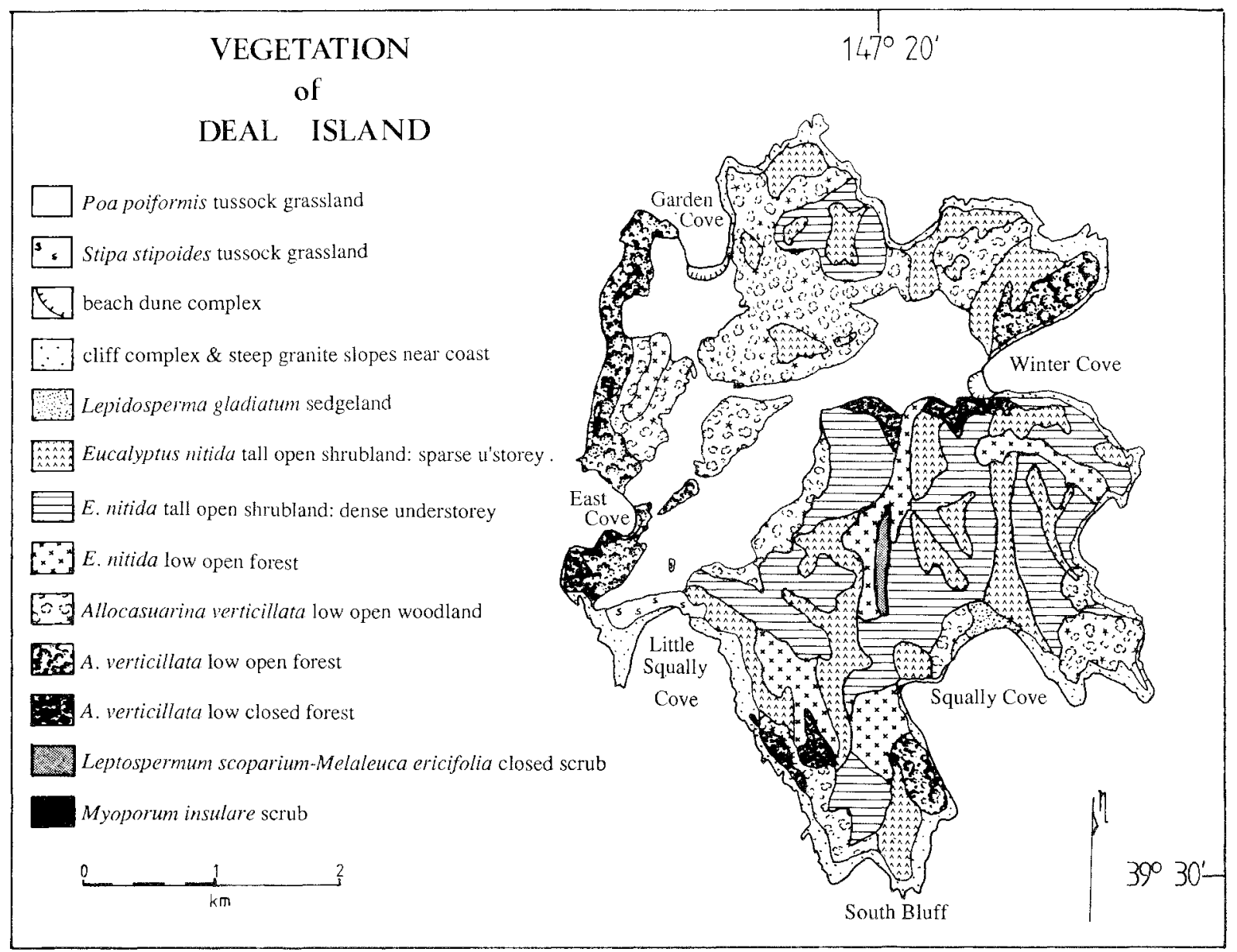

FIG. 2 - Vegetation of Deal Island.

surface. Most of the soil is completely bare. There are a small number of granite boulders strewn about, derived from upslope weathering. The Myoporum trees occur in a very shallow, broad depression running uphill from the shore.

The community is very species poor, which must be largely due to the low light levels under the canopy of the closed scrub. Threlkeldia diffusa appeared to be struggling for survival under the canopy, and only Rhagodia candolleana and Poa poiformis occur in the patches where there is more light. On the edges of the Myoporum scrub, Tetragonia implexicoma forms dense climbing mats over shrubs and fallen trees.

\section{Leptospermum scoparium-Melaleuca ericifolia Closed Scrub}

The only notable patch occupies about 6 ha or about $0.4 \%$ of the island. There are small discontinuous patches on Little Squally Creek which escaped the 1987 fire. Small patches also occur on the middle reaches of Garden Cove Creek. The largest patch occurs in an elevated, broad, shallow gully in the central southeast of the island, at the headwaters of Winter Cove Creek.

This large patch occurs on black, peaty soil overlying siliceous colluvial gravel derived from the weathering of adjacent granite hills. This colluvium may be fairly deep, which would act as a large "sponge", enabling slow release of groundwater in to one of the only three reliable creeks on the island.

The largest patch comprises Melaleuca ericifolia, Leptospermum scoparium and Callitris rhomboidea between about 3 and $3.5 \mathrm{~m}$ height. There is occasional emergent Eucalyptus nitida, while the understorey is mostly leaf litter with partial moss cover and some bare ground. The small patches on Little Squally Creek and Garden Cove Creek are dominated by $M$. ericifolia.

\section{ANALYSIS OF THE FLORA}

There were 176 vascular plant taxa from 63 families recorded from the island in May 1990 and on a very brief subsequent trip in December 1990. Our list contains 44 exotic species, 12 of which are grasses. The number of exotics recorded, therefore, comprises about one-quarter of the flora, but this proportion could be expected to increase if a more thorough collection was made in the pasture and garden areas around the lightstation.

The "complete census" of the island flora was compiled by Baron Von Mueller in 1884 from specimens collected by the lighthouse keeper. He recorded Eucalyptus obliqua but none can be found today on the island. E. nitida is widespread, yet no other eucalypt appears on Von Mueller's list. This suggests that $E$. nitida may have been mistaken for $E$. obliqua, possibly on the basis of an incomplete 
specinen, as we previously suggested (Harris \& Davis 1990). The possibility of misidentification is also supported by Whinray (1993).

Von Mueller again identified a list of plant species collected from the Kent Group by the expedition of the Field Naturalists Club of Victoria (Le Souef 1891). There were 84 species (excluding exotics) recorded, but there is no indication of which of the islands the species are from. Goodia lotifolia has also been identified, but Phyllanthus gunni, to which it bears a superficial resemblance and which is very common on parts of the island, was not listed. We did not see $G$. lotifolia. Von Mueller draws particular attention to several species as being noteworthy. One is Didymotheca thesioides (Gryostemon thesioides). This species was recorded by us as common in patches on the island but appears uncommon to rare elsewhere in Tasmania. Von Mueller (Le Souef 1891) implies that the species is uncommon on mainland Australia, and Willis (1972) does not list the species for Victoria. Other noteworthy species are those classified as rare in Tasmania (Flora Advisory Conmittee 1994): Lepidiurn pseudotasmanicum, Apium insulare, Apalochlamys spectabilis, Gyrostemon thesioides, Ixiolaena supina, Parietaria debilis, Pomaderris paniculosa ssp. paralia, Zygophyllum billardieri and Centrolepis pulvinata. Gullen et al. (1990) list Asplenium obtusatum as vulnerable in Victoria. However, it is frequent and secure in shaded crevices and overhangs around the rocky coasts of Tasmania and has been recorded from many locations in the Furneaux group.

Pratia irrigua R.Br. was collected from a Carex apressa Gahnia sedgeland on a slope above Little Squally Creek, in the damp ground associated with a spring seeping out from under the limestone cap on the granite. Previously taken to be endemic to the island, the species is now considered to be within the morphological range of $P$. platycalyx (Albrecht 1992).

A plant list compiled by G.K. Thompson (source of data unspecified) is given in Hope \& Hope (1968). This lists 64 species of vascular plants specifically for Deal Island but again Goodia lotifolia is listed and not Phyllanthus gunnit. Eucalyptus obliqua is also listed for the island in addition to E. amygdalina (E. nitida). A further 36 species are listed as general records for the Kent Group.

Whinray (1971b) lists 76 species of vascular plants from Deal Island which at the time were new to the island. Of these, 44 were exotics.

It is hoped that publication of the present species list for the island will stimulate botanical visitors to the island to add further records. We believe an annotated checklist of flora of the Kent Group is needed which would include records scattered in various herbaria.

\section{DISCUSSION}

Deal Island is in many ways typical of islands in eastern Bass Strait in terms of vegetation. The major formations dominated by Poa tussock and Allocasuarina are common. Eucalyptus nitida communities are common on Flinders Island. The plant species list recorded on Deal Island is also very similar to that of other islands in the Furneaux Group (S. Harris and A. Buchanan, unpubl. data). As with the other Furneaux Islands, the vegetation patterns reflect the same influence by humans. The dominant influences on vegetation patterning are salt spray, fire, human activity and soil fertility (limestone versus granite).

Exposure to salt spray imposes a major dichotomy in patterning of plant communities which generally overrides geology type (Harris \& Kirkpatrick, 1982) and is a general feature of islands. The typically coastal vegetation is distinguished by salt/drought adapted herbs and shrubs in the genera Chenopodiaceae and Aizoaceae. The most salttolerant zones can expand inland, as a result of burning or clearing into the scrub or woodland behind the usually narrow Stipa stipoides zone. If a wooded island is repeatedly burnt, it will convert to tussock grassland, where soils are reasonably fertile, and the greater exposure will result in greater input of salt to the ground, therefore favouring the more salt-tolerant vegetation usually found only in a narrow band.

Firc has had a dominating influence on present vegetation patterns in the islands. Islands have often been burnt to extend and maintain the tussock at the expense of woodland and forest communities. This has been the case on Deal Island, where Garreau (1958) commented that

"Very numerous is the Dropping Sheoke (Casuarina stricta) but this lovely old tree is slowly losing ground due to the annual burning off killing young ones."

Away from the coast, soil fertility is a major factor in determining vegetation patterning. There are two lithological types of the island - granite and limestone. The granite dictates the rugged nature of the island and forms very uneven topography. Soils are of variable depth but are mainly skeletal and acid, and the major plant communities which occur are Eucalyptus nitida forests, woodlands and shrubland.

The limestone occurs as a thin veneer on the island and remains on the area of more even topography. The area covered by Poa tussock broadly coincides with the area of limestone. The soils on the limestone are alkaline and shallow. There are some areas at the surface forming broken rocky ground. This kind of substrate generally has retained Allocasuarina forest or woodland. Eucalypts are generally not tolerant of high $\mathrm{pH}$ soils (Pryor 1976), therefore most of the area occupied by Poa tussock grassland was probably occupied formerly by Allocasuarina forest.

The search for a distinctive discontinuity in Bass Strait, between the Tasmanian and mainland floras would result in disappointment. The boundary between Tasmanian and mainland fauna is much more distinct, and Deal Island is close to that boundary (Hope 1972).

There is a more complicated pattern for flora distribution, with the most interesting aspect being the existence of a dry southern Australian and eremean component of the flora, reaching its southernmost extension in the relatively more reliable rainfall areas of eastern Bass Strait. This paradox is only apparent because the abundance of Tertiary limestone throughout the Furneaux Group and Kent Group provides a substrate which requires a drought tolerant flora, especially as high salt concentrations in onshore winds exacerbate drought conditions. Examples of species and genera which represent this group include Threlkeldia diffusa, Ixiolaena, Zygophyllum, Gyrostemon and (in the Furneaux Group) Frankenia and Sicyos.

A distinct Bassian floristic element is also represented throughout the Bass Strait islands and the limestone coasts of southern Victoria, Kangaroo Island and the southern 
Vegetation and flora of Deal Island, Bass Strait.

part of the Eyre Peninsula. This element is represented on Deal Island by species such as Apium insulare, Ixiolaena supina, Pomaderris paniculolsa ssp. paralia and Swainsona lessertifolia. Taxa near the limits of their distributions, occurring on Deal Island, include Sarcocornia quinqueflora ssp. tasmanica, Posidonia australis, Eucalyptus nitida and Centrolepis pulvinata. Asplenium obtusatum is listed by Gullen et al. (1990) as vulnerable in Victoria.

The number of exotic species on the island is much higher than on islands such as Rodondo or Dover Island, but most other islands of comparable size in eastern Bass Strait have a very high exotic species component, reflecting the long history of European activity in these islands.

Species invasion is still occurring on the coasts. A small patch of Ammophila arenaria occurs on the beach at Winter Cove. Euphorbia paralius is a recent invader of sandy beaches on southern Bass Strait coasts. The species was first noted in 1988, as only a few plants at East Cove, on Deal Island, by the wife of the Head Lightkeeper (Shirley Gray, pers. comm.). Shortly afterwards it expanded into what is now a dense infestation on the foredune.

Inventory of the flora on the islands scattered through Bass Strait and an understanding of their ecology and vegetation history provide information which is crucial to nature conservation planning and management, as well as useful data for archaeologists, biogeographers and others. It is hoped that this paper contributes to these aims.

\section{ACKNOWLEDGEMENTS}

We dedicate this paper to Stan and Shirley Gray, and Max and Linda Lucas, the last of the lightkeepers on Deal Island. We thank them for their memorable hospitality. We also thank the Australian Maritime Safety Authority for transport to and from the island. The Australian Heritage Commission funded the survey and initial report and Jonathon Miller of the Commission was most helpful. Assistance with identification or confirmation of some of the species was provided by Alex Buchanan of the Tasmanian Herbarium. We thank Dr Beth Gott of the Department of Evolutionary Biology at Monash University for useful discussions about the Kent Group, and Drs Neil Gibson and Mick Brown for comments on the manuscript.

\section{REFERENCES}

Albrecht, D.E., 1992: Pratia platycalyx is a synonym of $P$. irrigua (Campanulaceae: Lobelioideae). Pap. Proc. R. Soc. Tasm. 126: 123-124.

Bennett, I. \& Pope, E.C., 1960: Intertidal zonation of the exposed rocky shores of Tasmania and its relationship with the rest of Australia. Aust. J. Mar. Freshw. Res. 11: I82-221.

Bowdler, S., 1984: Hunter Hill, Hunter Island. Terra Australis 8. R.S.Pac.S. Dep. Prehist., ANU, Canberra.

Buchanan, A.M., McGlary-Brown, A. \& Orchard, A.E., 1980: A census of the vascular plants of Tasmania. Tasm. Herb. Occ. Publ. 2.

COLLINS, D., 1802: AN ACCOUNT OF THE ENGLISH COLONY IN NEW SOUTH WALES. VOL. II. (Republished by the Royal Australian Historical Society, Fletcher, B.H., Reed, A.H. \& A.W. [Eds], Sydney 1975.)
CORNELL, C. (Ed.), 1974: THE JOURNAL OF POST CAPTAIN NICOLAS BAUDIN. Libraries Board of South Australia, Adelaide.

EDGAR, G., 1984: Marine life and potential marine reserves in Tasmania. Part 2. Tasm. Nat. Pks Wildl. Serv. Occ. Pap. 7: $1-102$.

FIORA AIJVISORY COMMIT IEF, 1994: NATIVE HIGHER PLANT TAXA WHICH ARE RARE OR THREATENED IN TASMANIA. EDITION 1. Species at risk, Tasmania Flora. Parks \& Wildlife Service, Tasmania.

Garrfau, C.A., 1958: Excursion holiday in the Kent Group. Vict. Nat. 75: 128-130.

Guilan, P.K., Chrat, D.C. \& Walsh, N.G., 1990: RARE OR THREATENED PLANTS IN VICTORIA. Dep. Conserv. Environ., Melbourne.

Harris, S. \& Dnvis, G., 1990: Flora and Fauna of Deal Island. Unpubl. rep. Aust. Heritage Commn, 39 pp.

Harris, S. \& KirkPAIrICK, J.B., 1982: The vegetation of Schouten Island. Pap. Proc. R. Soc. Tasm. 116: 117-141.

Hope, J.H., 1972: Bass Strait, its coasts and islands: a symposium. Roy. Soc. Vict. Proc. 85(2).

Hope, J.H. \& Hope, G.S., 1968: A field guide to the Kent Group, Bass Strait. Unpubl. manuscript, Parks and Environment Library, Dep. Environ. Land Manage., Hobart.

JontS, R., 1969: Bass Strait in prehistory. In Murray-Smith, S. (Ed.): BASS STRAIT: AUSTRALIA'S LAST FRONTIER. Australian Broadcasting Commission, Sydney: 26-31.

King, R.J., 1973: The distribution and zonation of intertidal organisms in Bass Strait. Roy. Soc. Vict. Proc. 85: 145-63

Kuiter, R., 1981: The inshore fishes of the Kent Group in Bass Strait. Vict. Nat. 98:184-187.

LAST, P.R., 1979: First records of the one spot puller (Chromis bypsilepis) and the spotted stingaree (Urolophus gigas) from Tasmanian waters with an annotated list of fishes recorded from Kent Islands, Bass Strait. Tasm. Nat. 59: 5-12.

Le: SOUEF, D., 1891: Expedition of Field Naturalists' Club to Kent Group, Bass Straits. Vict. Nat. 7(9): 120-139.

MUfi..ER, F. VON, 1885: A complete census of the flora of Deal Island, Kent's Group. Pap. Proc. R. Soc. Tasm. 1884: 282-283.

Murray-Smith, S., 1979: MISSION TO THE ISLANDS. The missionary voyages in Bass Strait of Canon Marcus Brownrigg 1872-1885. Cat and Fiddle Press, Hobart.

Murray-Smith, S., 1980: Letter to Mr Peter Murrell 20 November 1980. Held on file 50-27-40 vol.1. Dep. Environ. Land Manage., Hobart.

OrChistor, D.W., 1984: Quaternary environmental changes and Aboriginal man in Bass Strait, Australia. Man and Environ. 8: 49-60.

Plomley, N.J.B. (Ed.), 1966: FRIENDLY MISSION. The Tasmanian journals and papers of George Augustus Robinson, 1829-34. Tasm. Hist. Res. Ass., Hobart.

PRYOR, L., 1976: THE BIOLOGY OF EUCALYPTS. Inst. Biol. Stud. 61. Edward Arnold, London.

Whinray, J.S., 1971a: A list of birds of the major Kent's Group Islands Tasm. Nat. 24: 2-3.

Whinray, J.S., 1971 b: Collecting the Kent's Group endemics. Tasm. Nat. 25: 2-6.

WhinRAY, J.S., 1993: A census of the plants of Deal Island, Kents Group, for 1884. Vict. Nat. 110 (6): 247-250.

WILLIS, J.J., 1972: A HANDBOOK TO PLANTS IN VICTORIA. VOL. II DICOTYLEDONS. Melbourne University Press.

(accepted 13 December 1994) 


\section{APPENDIX I}

List of vascular plants recorded from Deal Island, May 1990. Many of the collected specimens have been lodged in the Tasmanian Herbarium (HO). Species nomenclature follows Buchanan et al. (1989). (I) following species name =introduced taxa; $(\mathrm{E})=$ taxa endemic to Tasmania and offshore islands.
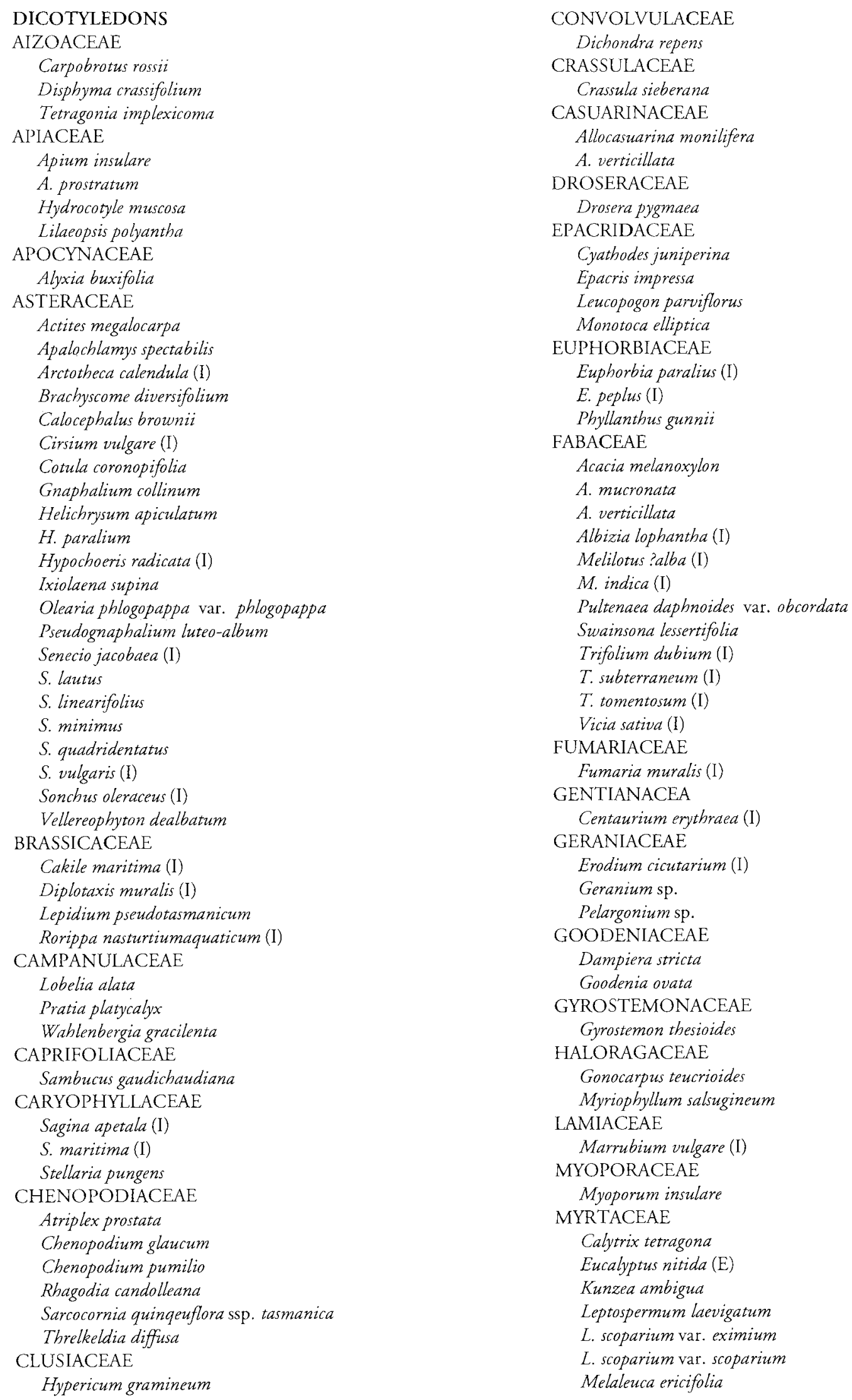
ONAGRACEAE Epilobium billardierianum

OXALIDACEAE

Oxalis perennans

PITTOSPORACEAE

Bursaria spinosa

PLANTAGINACEAE

Plantago coronopus (I)

POLYGONACEAE

Rumex acetosella (I)

PORTULACEAE

Calandrinia calyptrata

PRIMULACEAE

Anagallis arvensis (I)

PROTEACEAE

Banksia marginata

RANUNCULACEAE

Clematis microphylla

Ranunculus sp.

RHAMNACEAE

Pomaderris aspera

P. paniculosa ssp. paralia

RUBIACEAE

Galium australe

Opercularia varia

Sherardia arvensis (I)

RUTACEAE

Correa alba

C. ?backhousiana

Ziera arborescens

SAPINDACEAE

Dodonaea viscosa

SCROPHULARIACEAE

Verbascum thapsus (I)

SOLANACEAE

Solanum laciniatum

S. nigrum (I)

STACKHOUSIACEAE

Stackhousia monogyna

STYLIDIACEAE

Stylidium graminifolium

THYMELAEACEAE

Pimelea linifolia

URTICACEAE

Parietaria debilis

Urtica incisa

ZYGOPHYLLACEAE

Zygophyllum billardieri

\section{GYMNOSPERMS}

CUPRESSACEAE

Callitris rhomboidea

\section{PTERIDOPHYTES}

ASPLENIACEAE Asplenium obtusatum

BLECHNACEAE

Blechnum nudum

CYATHEACEAE Cyathea australis

DENNSTAEDTIACEAE

Histiopteris incisa

Hypolepis rugosula

Pteridium esculentum

Pteris tremula
DICKSONIACEAE

Dicksonia antarctica

SCHIZAEACEAE

Schizaea bifida

SINOPTERIDACEAE

Pellaea falcata

\section{MONOCOTYLEDONS}

ARACEAE

Zantedeschia aethiopica (I)

CENTROLEPIDACEAE

Centrolepis fascicularis

C. pulvinata (E)

C. strigosa

CYPERACEAE

Baumea acuta

B. juncea

Carex appressa

Carex sp.

Gabnia filum

G. trifida

I. auklandica

I. cernua

I. inundatus

I. nodosus

L. concavum

L. gladiatum

Schoenus nitens

IRIDACEAE

Iris sp. (I)

JUNCACEAE

Juncus bufonus

J. krausii

J. pallidus

J. pauciflorus

Luzula flaccida

JUNCAGINACEAE

Triglochin striata

ORCHIDACEAE

Pterostylis longifolia

POACEAE

Agrostis avenaceae

Aira caryophyllea (I)

Ammophila arenaria (I)

Anthoxanthum odoratum (I)

Briza minor (I)

Bromus diandrus (I)

Catapodium rigidum (I)

Cynosurus echinatus (I)

Danthonia caespitosa

D. racemosa

Holcus lanatus (I)

Pennisetum clandestinum (I)

Poa annua (I)

P. Labillardieri

P. poiformis

Polypogon maritimus (I)

P. monspeliensis (I)

Spinifex sericeus

Stipa flavescens

S. stipoides

TYPHACEAE

Typha orientalis 